\title{
Revisiting the Monthly Effect for the Chinese Stock Markets
}

\author{
Chin-Shan Hsieh ${ }^{1}$ \\ ${ }^{1}$ Assistant Professor, Department of Marketing and Distribution Management, Kao Yuan University, Taiwan. Tel: \\ 886-7-6077971-2381. \\ Correspondence: Chin-Shan Hsieh, Assistant Professor, Department of Marketing and Distribution Management, Kao \\ Yuan University, Taiwan.
}

Received: December 28, 2015

Accepted: January 30, 2016

Available online: February 4, 2016

doi:10.11114/aef.v3i2.1271

URL: http://dx.doi.org/10.11114/aef.v3i2.1271

\begin{abstract}
This study uses stochastic dominance (SD) theory, a distribution-free, omitted risk-adjusted method and allowing investors to allocate their assets between risky and risk-free assets, to test whether the monthly effect exists in the Chinese stock markets. The results show that March effect and March size effect are found in the Chinese markets, which findings are obviously different from the January effect and January size effect in the US and some developed markets. Consumption inertial hypothesis is used to explain the particular phenomena in the Chinese markets. Compared with previous findings, our empirical results in the Chinese markets also suggest that second-order SD with a risk-free asset (SSDR) for March effect replaces first- or second-order SD (FSD or SSD) for January effect in the US and some Asian markets, which result implies that allocating investor's assets between risky and risk-free assets can help distinguish the performance among the calendar months.
\end{abstract}

Keywords: Monthly Anomaly, Stochastic Dominance Theory, Efficient Set

\section{Introduction}

The January effect is perhaps the best-known calendar anomaly on the developed stock markets. The January effect is particularly intriguing because it doesn't appear to be diminishing despite being well known and publicized for several decades. In spite of the fact that its related issues are unpopular in recently academic journals, some famous TV programs or magazines, like CBSNEWS Business Report and Wall Street Journal, still continue reporting the January anomaly in the stock markets. ${ }^{1}$

Wachtel (1942) was the first to point out, almost seven decades ago, that the existence of returns on stocks in January were significantly larger than in any other calendar month on the Dow Jones Industrial Average. Rozeff and Kinney (1976) subsequently undertook the first rigorous empirical study of the January effect on the NYSE. Banz (1981) and Reinganum (1983) have noted that about fifty percent of the average magnitude of the size anomaly was due to January abnormal returns. Later studies also found an appearance of January effect in the US stock markets, ${ }^{2}$ with most of these studies noting that the anomaly which is referred as January size effect by Rogalski and Tinic (1986) is particular strong for small firms.

Other (non-US) developed stock markets also exhibit abnormally high rates of returns in January; for example, the effect has been highlighted by Officer (1975) in the Australian capital markets, Tinic et al. (1987) in the Canadian markets, Aggarwal et al. (1990) in the Tokyo Stock Exchange, Barone (1990) in the Milan Stock Exchange, and also by Gultekin and Gultekin (1983) in the markets of seventeen industrialized nations. Unusually higher returns have also been reported in January than in any other month for some of the emerging markets; for example, Nassir and Mohammad (1987) provided the evidence of the January effect in Malaysia, while Pang (1988) reported similar findings for Hong Kong. Ho (1990) and Lean et al. (2007) reported support for the existence of the January effect in

\footnotetext{
1. Examples included: The article of " The January Effect vs. the January Barometer ", written by Hirsch (2009), is available from the Wall Street Journal Website (http://www.marketwatch.com). The other article of "As Goes January, So Goes The Year? ", also appeared in the CBSNEWS (Jan. 30, 2009), is available from the Website (http://www.cbsnews.com).

${ }^{2}$. Examples include: Haugen and Jorion (1996), Haug and Hirschey (2006) and Moller and Zilca (2008).
} 
some of the Asian markets as well. ${ }^{3}$

The underlying reasons for the existence of the January effect in the stock markets are not well understood, although a plausible explanation for the higher returns in January is tax-loss selling pressure; the suggestion is that individual investors, who invariably have only small stockholdings, will tend to sell losers in December for tax reasons and repurchase similar stocks in the following month. ${ }^{4}$

An alternative potential explanation, which is emphasized in a number of studies, 5 for the observed January effect is stressed by window dressing strategy. In their efforts to avoid reporting too many year-end losers in their institutional portfolios, institutional investors may tend to sell their losers in December, and then buy back the same stocks after the reporting period in January in order to re-establish their desired portfolio; such actions thereby cause January returns to outperform all other months.

Owing to the fact that most developed countries impose a tax on capital gains in their stock markets; Shanghai and Shenzhen stock markets, two important Chinese markets, can act as a counter instance because there are no taxes on their capital gains. Therefore, tax-loss selling pressure should not be observable in the Chinese stock markets in December. Next, Kling and Gao (2004) have documented that, as compared to other stock markets, the role played by institutional traders is of far less importance in the Chinese markets. Hence, institutional investors do not tend to sell losers for window dressing in December and do not put buying pressure on small stocks at the turn of the year. Thus, based upon the above discussions, if monthly patterns are found to exist in the Chinese markets, then there appears to be a requirement for alternative explanations.

There would seem to be no general consensus in the literature as to why the monthly effect exists or whether this is indicative of an inefficient market. As noted Fama (1970) and Seyhun (1993), most tests of market efficiency are essentially joint tests of market efficiency and the model of expected returns. As a result, it is quite difficult to determine whether a rejection of joint hypothesis would actually imply market inefficiency or/and mis-specified model of expected returns. Kim (2006) recently emphasized that a strong January effect might result from the mis-specified of models in the calculating abnormal returns.

To avoid the above argumentations, a non-parametric stochastic dominance (SD) theory, used raw returns (unadjusted for risk), has been used to investigate whether the monthly effect actually exists in the stock markets. Seyhun (1993) used the SD approach to examine whether the January effect existed in the US markets, while Lean et al. (2007) carried out similar analyses for some Asian stock markets. Seyhun found that the January returns in the smallest portfolio of NYSE firms dominate the January returns for all other portfolios by the first-order stochastic dominance (FSD), while Lean et al. found that FSD for January effect had largely disappeared in some of the Asian markets.6

It should be noted that in above both studies, the performance of the month-size portfolios was distinguishable by the stochastic dominance without risk-free assets; that is, the FSD, SSD and TSD rules, without mixing the risky assets and risk-free assets, can distinguish among the performance of their month-size portfolios. However, if the dominance relationship among portfolios cannot be clearly distinguished by stochastic dominance without risk-free rate; then stochastic dominance with risk-free assets (SDR) must be adopted for further comparison among the portfolios' returns, which is a prominent feature of the present study. That is, an attractive feature of the SDR rules is that investors are allowed to invest part of their money in risky assets (e.g. stock portfolio) and part of their money in risk-free assets; 7 thus, the SDR rules provide investors a useful tool for their assets allocation, which implies that investors' assets between risky and risk-free assets can be allocated into an optimal ratio.

Compared with previous findings, our first empirical results in the Chinese stock markets suggest that second-order stochastic dominance with a risk-free asset (SSDR) for March effect replaces first- or second-order stochastic dominance (FSD or SSD) for January effect in the US and some Asian stock markets.

The second results reveal that March returns for all size-directed portfolios and market index (MI) respectively dominate their non-March returns, which findings are referred to "strong March effect" in this study. Furthermore, the returns of the smallest firm size portfolio (Portfolio 1) in March are dominant over all of the other month-size portfolios

\footnotetext{
3 . Many studies have also found different patterns or the disappearance of January effect for stock returs; for example, Bhabra et al. (1999) documented the existence of both January and November effects in the US markets after the promulgation of the 1986 Tax Reform Act, while Mehdian and Perry (2002) and Gu (2003) noted that the January effect disappeared at a statistical level after 1987 and Kim (2006) recently has found that when the raw returns are adjusted by a two-factor model, the abnormal January returns across firm sizes have disappeared in the US markets.

4. See Branch (1977), Reinganum (1983), Rozeff (1986) and Chen and Signal (2004).

5. Examples included: Dyl (1977), Lakonishok and Smidt (1984), Haugen and Lakonishok (1988), Ritter and Chopra (1989), Lakonishok et al. (1991) and Gompers and Metrick (2001).

6 . Note that the Chinese stock markets were not examined in the study of Lean et al. (2007).

7 . The features of SD theory will be described in Section 3.
} 
and all monthly market index returns, which we refer it as "strong March size effect". As noted above, January effect and January size effect were found in the US and some developed markets, which apparently differ from our findings in the Chinese markets.

The third results show that December returns for all size-directed portfolios and market index are respectively dominated by their non-December returns, which findings are referred to as "weak December" effect in this study. In addition, December returns of the smallest firm size portfolio (Portfolios 1) are dominated by all of the other month-size portfolios and all monthly market index returns, which are referred to as "weak December size" effect.

The remainder of this paper is organized as follows: A brief introduction of the Chinese stock markets is provided in Section 2, followed in Section 3 by an explanation of our methodology and hypothesis. Our empirical results are presented in Section 4. Finally, the conclusions drawn from this study are presented in Section 5.

\section{Brief Introduction of the Chinese Stock Markets}

The two major exchanges in China are the Shanghai Stock Exchange (SSE) and the Shenzhen Stock Exchange (SZE). The SSE, founded on 26 November 1990, began operations in December of the same year, while the SZE was also established on 1 December 1990. Two types of shares, A shares and B shares, are traded on both exchanges, and indeed, the same firm can issue both types of shares. A shares, denominated and settled in Yuan or Renminbi (RMB), are issued only to domestic investors, while B shares, issued in US dollars on the SSE and in Hong Kong dollars on the SZE, were initially issued only to foreign investors; however, from 28 February 2001 onwards, Chinese investors were allowed to open foreign exchange account to trade in B shares. There is also a plan to eventually merge the two types of shares. The relative trading value and volume of B shares to A shares are small, so we focus on the study of A shares.

As part of an emerging and transitional economy, the Chinese stock markets are currently experiencing rapid development and expansion. As shown in Table 1, by the end of December 2010, the number of SSE-listed firms increased to 894, with a total market value of US\$2,176 billion and stock turnover rate of 178.47 per cent. Over the same period, the number of SZE-listed firms rose to 1169 , with a total market value of US\$1,311 billion and a stock turnover rate of 344.27 per cent. There are several noteworthy features of both the SSE and SZE.

Firstly, the market capitalization of the Chinese stock markets has developed rapidly over recent years. The official Shanghai Securities News reported that the total market capitalization of the Chinese stock markets has overtaken Japan in 2010. ${ }^{8}$ The report by the Focus Monthly Statistics of World Federation of Exchanges (2010) also revealed that the increase in market capitalization in the Chinese markets was far more rapid than in any of the other global markets; ${ }^{9}$ indeed, stock market capitalization in China has now become the first largest in Asia and is second largest stock market behind the US. ${ }^{10}$

Secondly, the average market returns for both exchanges, as shown in Table 1, outperformed both the most developed and emerging markets during the 1995-2010. The SSE had average yearly returns of 20.24 per cent, while the average for the SZE was 31.25 per cent during the study period. Both exchanges surpassed the leading markets of the world, including the NYSE (8.75 per cent), the LSE (5.64 per cent), the TSE ( -1.55 per cent), the HKSE (11.26 per cent), the SGSE (7.06 per cent) and the TWSE (6.34 per cent) ${ }^{11}$ It therefore comes as no surprise that the outstanding investment accomplishments of the two exchanges are accompanied by higher risk. The standard deviation in the Chinese markets was far greater than the other developed and emerging markets during the sample period.

Thirdly, a high P/E generally suggests that investors are expecting higher earnings growth in the future compared to firm with a lower P/E. ${ }^{12}$ As Table 1 shows, over the past decade, SSE- and SZE-listed firms exhibited higher P/E ratios than those of most of the developed and emerging markets, with the one notable exception of the TSE. Over the same period, average turnover for the SSE (189.79 per cent) and the SZE (254.26 per cent) was also considerably higher than the other developed and emerging markets during the study period.

Finally, economic development in China remains among the most rapid in the world, with an average annual growth rate of 9.8 per cent in gross domestic product (GDP) over the past 30 years. ${ }^{13}$ As at the end of 2010, GDP in China

\footnotetext{
${ }^{8}$. See January 13, 2011, China Network Television Report.

9. This information is available from the website of World Federation of Exchanges.

${ }^{10}$. See January 5, 2011, Wall Street Journal.

${ }^{11}$. NYSE, LSE, TSE, HKSE, SGSE and TWSE respectively refer to the New York Stock Exchange, London Stock Exchange, Tokyo Stock Exchange, Hong Kong Stock Exchange, Singapore Stock Exchange and Taiwan Stock Exchange.

12. The P/E ratio measures the amount that investors are willing to pay for each dollar of a firm's earnings.

13. This information is from the National Bureau of Statistics of China (2009).
} 
stood at US\$5.98 trillion, with official foreign exchange reserves exceeding US $\$ 2.85$ trillion. ${ }^{14}$ The economy of China is now the second largest in the world, regardless of whether this is measured by GDP or the trading amount of exports and imports, 15 while its stock markets, as noted above, are expected to become the second largest in the world. Therefore, it is considered to be important to examine stock price behavior in the Chinese stock markets.

Table 1. Market Characteristics of Some World's and Asian Major Markets during the 1995-2010

(a) During the 1995 to 20101

\begin{tabular}{ccccccccc}
\hline $\begin{array}{c}\text { Stock } \\
\text { Exchange }\end{array}$ & $\begin{array}{c}\text { Composite } \\
\text { Index }\end{array}$ & $\begin{array}{c}\text { Mean } \\
\text { Yearly Returns }(\%)\end{array}$ & $\begin{array}{c}\text { Market Value } \\
(\$ \text { Billion })\end{array}$ & $\begin{array}{c}\text { Trading } \\
\text { Value } \\
(\$ \text { Billion })\end{array}$ & $\begin{array}{c}\text { Trading Volume } \\
(\text { Billions of } \\
\text { Shares) }\end{array}$ & Turnover & P/E Ratio & $\begin{array}{c}\text { No. of } \\
\text { Stocks }\end{array}$ \\
\hline SSE & $1,876.53$ & $20.24(51.80)^{3}$ & 868.31 & $1,280.79$ & $773,466.38$ & 189.79 & 32.72 & 894 \\
SZE & 567.79 & $31.25(72.81)$ & 310.46 & 750.60 & $474,719.63$ & 254.26 & 35.67 & 1,169 \\
NYSE $^{2}$ & $9,860.41$ & $8.75(18.12)$ & $11,140.66$ & $11,944.68$ & $367,899.13$ & 101.13 & 25.36 & 2,317 \\
LSE & $5,279.44$ & $5.64(17.01)$ & $2,620.46$ & $3,663.88$ & $575,371.75$ & 88.04 & 17.28 & 2,966 \\
TSE & $13,711.13$ & $-1.55(22.42)$ & $3,302.31$ & $2,396.36$ & $317,447.75$ & 78.16 & 118.57 & 2,281 \\
HKSE & $15,364.23$ & $11.26(31.68)$ & $1,065.94$ & 622.01 & $8,757,758.13$ & 59.05 & 15.79 & 1,244 \\
SGSE & $2,204.52$ & $7.06(33.25)$ & 249.88 & 135.05 & $185,259.63$ & 56.11 & 23.02 & 651 \\
TWSE & $6,660.35$ & $6.34(32.23)$ & 408.34 & 776.25 & $697,981.94$ & 213.77 & 29.69 & 758 \\
\hline
\end{tabular}

(b) At $2010^{5}$

\begin{tabular}{ccccccccc}
\hline & Composite Index & $\begin{array}{c}\text { Yearly } \\
\text { Returns }(\%)\end{array}$ & $\begin{array}{c}\text { Market Value } \\
\text { (\$ Billion) }\end{array}$ & $\begin{array}{c}\text { Trading Value } \\
\text { (\$ Billion) }\end{array}$ & $\begin{array}{c}\text { Trading Volume } \\
\text { (Billions of Shares) }\end{array}$ & $\begin{array}{c}\text { Turnover } \\
\text { P/E Ratio }\end{array}$ & $\begin{array}{c}\text { So. of } \\
\text { Stocks }\end{array}$ \\
\hline SSE & $2,808.08$ & -14.31 & 2,716 & $4,496.19$ & $2,596,440$ & 178.47 & 21.62 & 894 \\
SZE & $1,290.87$ & 7.45 & 1,311 & $3,572.53$ & $1,618,752$ & 344.27 & 44.69 & 1,169 \\
\hline
\end{tabular}

1. The information in the table is taken from the annual reports of Taiwan Stock Exchange Corporation.

2. SSE, SZE, NYSE, LSE, TSE, HKSE, SGSE and TWSE respectively stand for Shanghai stock Exchange, Shenzhen stock Exchange, New York Stock Exchange, London Stock Exchange, Tokyo Stock Exchange, Hong Kong Stock Exchange, Singapore Stock Exchange and Taiwan Stock Exchange.

3. The figures in parentheses are standard deviation of index returns for each markets during the 1995-2010.

4. The last column (No. of Stocks) is the number of listed companies at the end of 2010.

5. The aim of Panel (b) is to provide readers with the fast growth situation of the Chinese stock markets in 2010.

\section{Methodology and Hypothesis}

\subsection{Methodology}

As noted above, SD rules are used to test the performance among various portfolios in this study. ${ }^{16} \mathrm{SD}$ theory is a useful tool for marking comparison among distributions without depending on a particular distribution form of returns and a particular

mathematical form of utility function. SD theory provides optimal investment criteria under uncertainty for all expected utility maximizes with given preference structures. In addition, SD methodology has further appeal since it allows investors to invest part of their money in the risky assets (e.g. stock portfolio) and part of their money in risk-free assets; that is, by utilizing SD theory, investors are provided with a useful tool for assets allocation, which implies that investors' assets between risky and risk-free assets can be allocated into an optimal ratio.

14. The details are obtained from the website of State Administration of Foreign Exchange, People's Republic of China. (see http://www.ustr.gov/countries-regions/china)

15. The amount of the Chinese exports and imports with world's markets in 2010 was $\$ 1,577.9$ and $\$ 1,394.8$ billion, respectively. (see http://www.uschina.org/statistics/tradetable.html)

${ }^{16}$. The stochastic dominance theory given here is slightly modified from Hadar and Russell (1969), Hanoch and Levy (1969), Levy and Kroll (1979), Seyhun (1993), Liao and Chou (1995), Levy (1998) and Best et al. (2000). The readers interested in more details about SD and SDR rules can consult Levy (1992), Elton and Gruber (1995) and Post (2003). 


\subsection{Hypothesis}

Ogden (1990) have documented that the most year's consumption expenditure of the people occurs around the Christmas season in the US markets; as a result of this, people earn more liquid profits in December than in other months. Some of these liquid profits are then reinvested into stock markets, which gives rise to a relatively large surge in stock returns in January. Using a multifactor model linking macroeconomic factors, such as the growth rate of consumption and so on, Kramer (1994) found that substantial seasonality was clearly discernible in expected returns. Lettau and Ludvigson (2001) found that the consumption-wealth ratio is a strong predictor of both real stock returns and excess returns over a T-bill rate in the US markets. Zang and Wang (2006) also reported the existence of a relationship between the growth rate of consumption and the asset returns in the Chinese stock markets. More recently, Budría (2008) showed that the growth rate of consumption was negatively (positively) correlated with future (past) stock returns in the US markets. A summary of these studies indicates that some macroeconomic factors may provide at least a partial explanation for the monthly effect in both developed and developing markets.

Table 2 shows that consumption expenditure, adjusted by the consumer price index, tends to peak around December while a trough occurs around March and April in China. Furthermore, Figure 1 illustrates the relationship between mean monthly growth rate of consumption (GRC) and the mean monthly returns for the smallest firm size portfolio (Portfolio 1), which represents that high and positive returns generally correspond to low and negative GRC, and vice versa. For example, low (high) GRC occurs in March (December), which corresponds to high (low) monthly returns.

Table 2. Mean and Standard Deviation of Monthly Consumption Expenditure during the Study Period ${ }^{1}$

\begin{tabular}{ccc}
\hline Month & Mean $^{2}$ & $\begin{array}{c}\text { Standard } \\
\text { Deviation }\end{array}$ \\
\hline Jan & 375.47 & 180.32 \\
Feb & 350.64 & 165.13 \\
Mar & 335.78 & 156.99 \\
Apr & 331.36 & 156.15 \\
May & 345.01 & 170.90 \\
Jun & 346.80 & 165.60 \\
Jul & 342.64 & 166.43 \\
Aug & 347.38 & 169.42 \\
Sep & 376.51 & 183.90 \\
Oct & 399.44 & 199.37 \\
Nov & 403.52 & 189.97 \\
Dec & 464.73 & 203.37 \\
\hline
\end{tabular}

1. The proxy of consumption expenditure is retail sales of consumer goods which is taken from the Monthly Reports of National Bureau of Statistics of China (2007). Note that retail sales of consumer goods refer to the sum of retail sales of commodities sold by wholesale, retail, catering, publishing, post and telecommunications and other service industries to urban and rural households for private consumption and to social institutions for public consumption.

2. The unit of measurement is in billions of RMB.

As noted above, tax-loss selling pressure and window dressing hypotheses may not provide any feasible explanation for the monthly effect in the Chinese markets, the implication of the previous literature and above discussion is that growth rate of consumption may be used to explain the monthly effect in the Chinese markets. We therefore propose the following hypothesis, which we refer to as the consumption inertial hypothesis: 17

Consumption Inertial Hypothesis: If the consumption inertial phenomenon exists between monthly growth rate of consumption (GRC) and monthly stock returns in the Chinese stock markets, it is expected that low monthly GRC corresponds to high monthly stock returns, and vice versa. That is, as GRC decreases (increases), the stock returns increases (decreases), as would be expected.

17. The consumption expenditure tends to peak around December while a trough occurs in around March and April. This consumption habit has an inertial, like the Newton's first law, so it is dubbed consumption inertial hypothesis. 


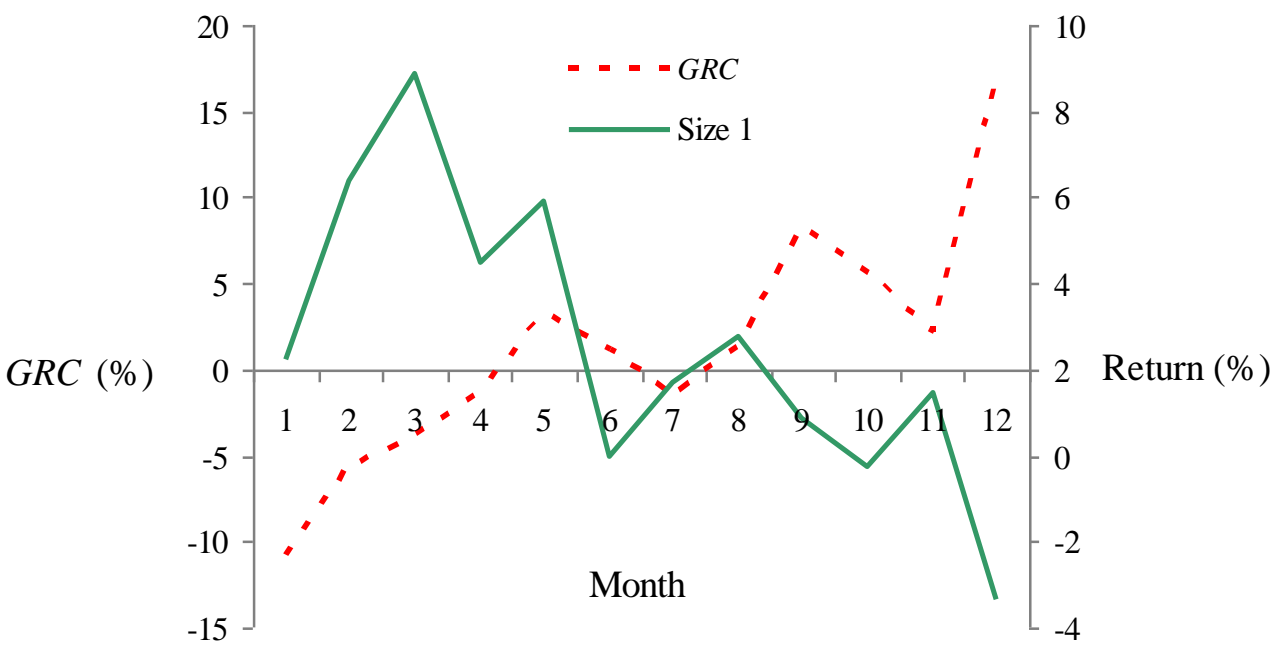

Figure 1. Mean Monthly Returns of the Smallest Firm Size-directed Portfolio and Mean Monthly Growth Rate of Consumption $(G R C)$ during the Study Period

\section{Empirical Results}

\subsection{Sample Characteristics}

The stock returns and relevant data used in this study are taken from the Taiwan Economics Journal Data Bank (TEJDB), with the sample shares comprising of Shanghai and Shenzhen A shares. The annual size cross-sections are sorted based on ascending market values and five portfolios are established at the beginning of each year according to the market values at the end of the previous year. Portfolio 1 comprises of firms with the lowest market values, with each subsequent portfolio containing the firms with the next highest market values; thus, Portfolio 5 contains of the firms with the highest market values. The monthly portfolio returns are formed by equally weighting each stock within each portfolio, all of which are re-balanced each year on the basis of their previous year-end capitalization levels.

The means and standard deviations of the monthly returns, based upon five size-directed portfolios and calendar months, are shown in Table 3. The sample period for the monthly returns data is January 1995 to December 2007. The average March returns of size-directed Portfolios 1 to 4 and the market index (MI) rank in first place in their respective portfolios, which findings show a tendency to exist the "strong March" effect. We can also see that all of the lowest average monthly returns for five size-directed portfolios and MI occur in December, which also show a tendency to exist the "weak December" effect. In contrast, the standard deviations of monthly stock returns do not display a similar seasonality.

\section{2 "Strong March" Effect and "Weak December" Effect}

\subsection{1 "Strong March" Effect}

The cumulative distribution functions (CDFs) of the February, March, May, June, October and December returns are illustrated in Figure 2 for the smallest firm size portfolio (Portfolio 1). Other months are omitted to reduce clutter. CDFs of the February and March are shifted most to the right, while the CDF of October and December are shifted most to the left during the most part of returns interval. A visual of the Figure 2 reveals that the February or March returns may outperform the other monthly returns for the smallest firm size portfolio by certain SD or SDR rules. 
Table 3. Means and Standard Deviations in Parentheses (in percent) for Monthly Returns during the Study Period

\begin{tabular}{ccccccc}
\hline \multicolumn{7}{c}{ Five Size-directed Portfolios } \\
\hline Month & 1 & 2 & 3 & 4 & 5 & MI \\
\hline \multirow{2}{*}{ Jan } & $2.25 \%$ & 2.92 & 3.41 & 3.27 & 3.36 & 3.04 \\
& $(11.00)$ & $(11.02)$ & $(11.40)$ & $(10.60)$ & $(10.25)$ & $(10.73)$ \\
Feb & 6.39 & 4.88 & 4.47 & 4.12 & 2.96 & 4.56 \\
& $(8.86)$ & $(8.00)$ & $(7.39)$ & $(6.82)$ & $(6.06)$ & $(7.32)$ \\
Mar & 8.85 & 7.43 & 5.90 & 5.69 & 4.46 & 6.45 \\
& $(11.41)$ & $(10.26)$ & $(8.74)$ & $(8.31)$ & $(7.12)$ & $(8.91)$ \\
Apr & 4.47 & 6.26 & 5.53 & 5.14 & 6.04 & 5.49 \\
& $(15.78)$ & $(17.07)$ & $(14.90)$ & $(13.67)$ & $(13.56)$ & $(14.78)$ \\
May & 5.93 & 5.02 & 4.07 & 3.72 & 3.70 & 4.47 \\
& $(12.89)$ & $(12.14)$ & $(10.72)$ & $(9.97)$ & $(9.72)$ & $(10.83)$ \\
Jun & -0.05 & 1.00 & 1.42 & 2.46 & 3.65 & 1.71 \\
& $(12.57)$ & $(13.26)$ & $(12.64)$ & $(14.17)$ & $(14.08)$ & $(13.10)$ \\
Jul & 1.72 & 1.72 & 1.18 & 1.02 & -0.13 & 1.09 \\
& $(1.11)$ & $(11.62)$ & $(10.16)$ & $(10.45)$ & $(8.84)$ & $(10.23)$ \\
Aug & 2.75 & 1.43 & 0.75 & 1.74 & 0.24 & 1.37 \\
& $(8.62)$ & $(7.60)$ & $(7.10)$ & $(7.38)$ & $(6.93)$ & $(7.16)$ \\
Sep & 0.87 & 0.08 & -0.26 & -0.46 & -0.98 & -0.15 \\
& $(7.37)$ & $(6.49)$ & $(6.29)$ & $(6.21)$ & $(5.85)$ & $(6.21)$ \\
Oct & -0.24 & 0.28 & 0.55 & -0.20 & -0.10 & 0.06 \\
& $(11.30)$ & $(11.56)$ & $(11.81)$ & $(9.44)$ & $(7.93)$ & $(10.25)$ \\
Nov & 1.48 & 0.92 & 0.56 & 0.25 & -0.14 & 0.61 \\
& $(5.78)$ & $(6.21)$ & $(5.43)$ & $(6.11)$ & $(6.64)$ & $(5.61)$ \\
Dec & -3.33 & -3.22 & -2.34 & -2.40 & -1.15 & -2.48 \\
& $(10.52)$ & $(10.49)$ & $(10.28)$ & $(9.94)$ & $(9.55)$ & $(10.06)$ \\
\hline
\end{tabular}

1. Portfolio 1 is the smallest-cap portfolio, while Portfolio 5 is the largest-cap portfolio. MI denote equal-weighted index of A shares. Note that the A shares are composed of Shanghai and Shenzhen A shares.

We are, of course, also concerned the dominance relationship for the other four size-directed portfolios and MI; therefore, the SD or SDR rules, as noted above, are used to examine dominance relationship among months' returns for the various portfolios. 18 The SDR tests use the risk-free rates ranging from 1.98 per cent to 10.98 per cent in our study period. ${ }^{19}$

Table 4 identifies those months for each size-directed portfolio and MI which appear in the stochastic dominance efficient sets without transaction costs during the study period. Some conclusions can be drawn from this table.

Firstly, using the weak assumption of a non-decreasing utility function, we can weakly distinguish among the months for five size-directed portfolios and MI. ${ }^{20}$

For example, February, March and April returns dominate the other nine months returns by the FSD rule (without lending and borrowing) for the smallest firm size portfolio (Portfolio 1). Similar results are also found for the other four size portfolios and $\mathrm{MI}^{21}$

18. The FSD, SSD, TSD, FSDR, SSDR and TSDR criteria are employed to test the monthly effect in this study.

19. The ${ }^{\text {risk-free rates }}$ of $\mathrm{t}^{\text {he SDR tests }}, r_{f}$ are ${ }^{\text {obtained from the website of People s Bank of China }}$.

20. As noted above, the returns on each portfolio are calculated by equally weighting each stock within the portfolio in this study. For the purpose of performance comparison among the market index and the various portfolios, returns on $\mathrm{m}^{\text {arket index }}$ (MI) also use the same way to calculate the returns for A shares of SSE and SZE. MI hereafter refer $\mathrm{s}$ to as $\mathrm{m}^{\text {arket index. }}$

21. In order to save space, some of the results of ${ }^{\text {stochastic dominance efficient sets are }}$ omitted in 4 Table 4. 


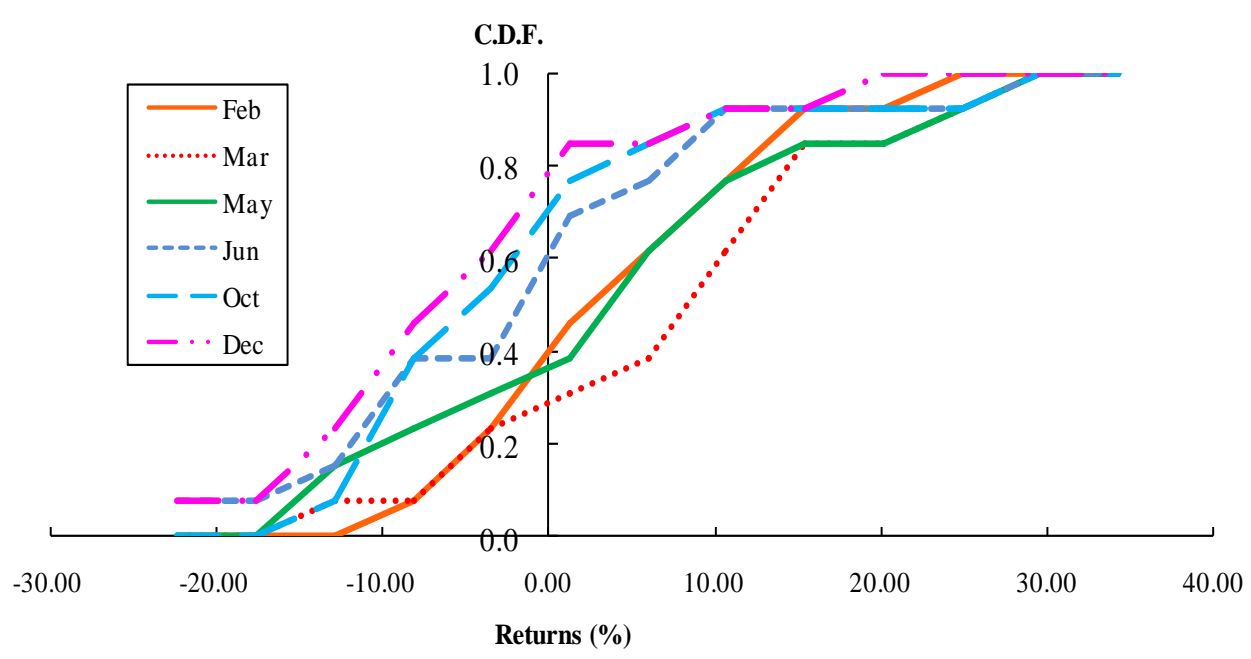

Figure 2. CDFs of the Monthly Returns for the Smallest Firm Size Portfolio 1 for the Months of February, March, May, June, October and December.

Allowing investors to borrow or lend money at a risk-free interest rate can slightly reduce the size of the FSDR efficig日t per cent. In order to sharp distinguish the performance of the various portfolios; further assumptions would be required on the preference structure of investors.

Secondly, assuming that preferences of investors are risk averse, the results of five size-directed portfolios and MI show that each SSD efficient set includes only two or three months; i.e., the other nine or ten months have been excluded from their respective efficient sets when SSD rule is used to examine the dominance relationship among twelve months for each size-directed portfolio. For example, only two months, February and March are included in SSD efficient set for Portfolio 1.

The results are stronger when investors are allowed to borrow or lend money at a risk-free interest rate. The SSDR efficient sets of Portfolios 1 to 4 and MI reveal that March returns clearly and respectively outperform all the other months' returns at certain levels of risk-free interest rate. The SSDR efficient set of Portfolio 5 also reveals that March and April returns outperform the other ten months' returns. In order to determine whether March returns dominate April returns, or vice versa, the TSD and TSDR rules are used to further test the dominance relationship between them.

Thirdly, if we make an additional assumption relating to decreasing absolute risk aversion, we can use the TSD and TSDR rules to test dominance relationship among the various portfolios. The results of TSDR efficient set of Portfolio 5, allowing investors to borrow and lend money at a certain risk-free interest rate, display that only March is included in the TSDR efficient set; i.e., March returns also dominate all the other months' returns.

In short, the results of Tables 4 reveal that March returns are superior to the performance of all the other months, namely "strong March" effect, for all of the five size-directed Portfolios and MI. We can therefore conclude that the "strong March" effect exists not only in the small-cap portfolio, but also in large-cap portfolios in the Chinese stock markets. This phenomenon apparently differs from the previous findings in the US and some developed markets.

Table 4. Efficient Sets of Five Size-directed Portfolios and Equally-Weighted Index

\begin{tabular}{|c|c|c|c|c|c|c|c|c|c|c|c|c|c|c|c|c|c|c|}
\hline & \multicolumn{4}{|c|}{ Portfolio $1^{3}$} & \multicolumn{4}{|c|}{ Portfolio 2} & \multicolumn{2}{|c|}{ Portfolio 3} & \multicolumn{2}{|c|}{ Portfolio 4} & \multicolumn{4}{|c|}{ Portfolio 5} & \multicolumn{2}{|r|}{ MI } \\
\hline & FSD & $\mathrm{SSD}^{2}$ & $\begin{array}{c}\text { FSDR } \\
r_{f} \geq 4.00 \%^{4}\end{array}$ & $\begin{array}{c}\text { SSDR } \\
r_{f} \geq 1.98 \%\end{array}$ & FSD & SSD & $\begin{array}{c}\text { FSDR } \\
r_{f} \geq 1.98 \%\end{array}$ & $\begin{array}{c}\text { SSDR } \\
r_{f} \geq 1.98 \%\end{array}$ & SSD & $\begin{array}{c}\text { SSDR } \\
r_{f} \geq 2.00 \%\end{array}$ & SSD & $\begin{array}{c}\mathrm{SSDR} \\
r_{f} \geq 10.0 \%\end{array}$ & SSD & TSD & $\begin{array}{c}\text { SSDR } \\
r_{f} \geq 1.98 \%\end{array}$ & $\begin{array}{c}\text { TSDR } \\
r_{f} \geq 1.98 \%\end{array}$ & SSD & $\begin{array}{c}\text { SSDR } \\
r_{f} \geq 1.98 \%\end{array}$ \\
\hline Jan & -1 & - & - & - & - & - & - & - & - & - & - & - & - & - & - & - & - & - \\
\hline Feb & + & + & + & - & + & + & + & - & + & - & + & - & + & + & - & - & + & - \\
\hline Mar & + & + & + & + & + & + & + & + & + & + & + & + & + & + & + & + & + & + \\
\hline Apr & + & - & - & - & + & + & + & - & - & - & - & - & + & - & + & - & + & - \\
\hline May & - & - & - & - & + & + & + & - & - & - & - & - & - & - & - & - & - & - \\
\hline Jul & - & - & - & - & + & - & - & - & - & - & - & - & - & - & - & - & - & - \\
\hline Aug & - & - & - & - & - & - & - & - & - & - & - & - & - & - & - & - & - & - \\
\hline Sep & - & - & - & - & - & - & - & - & - & - & - & - & - & - & - & - & - & - \\
\hline Oct & - & - & - & - & - & - & - & - & - & - & - & - & - & - & - & - & - & - \\
\hline Nov & - & - & - & - & - & - & - & - & - & - & - & - & - & - & - & - & - & - \\
\hline Dec & - & - & - & - & - & - & - & - & - & - & - & - & - & - & - & - & - & - \\
\hline
\end{tabular}


1. Efficient sets (winner) marked by "+", inefficient sets (loser) marked by "-".

2. FSD: first-degree stochastic dominance, SSD: second-degree stochastic dominance, TSD: third-degree stochastic dominance, FSDR: first-degree stochastic dominance with risk-free asset, SSDR: second-degree stochastic dominance with risk-free asset, TSDR: third-degree stochastic dominance with risk-free asset.

3. Portfolio 1 denotes the smallest-cap portfolio, Portfolio 5 denotes the largest-cap portfolio, and MI denotes the equal-weight Index. In order to save space, only the SSD, SSDR, TSD and TSDR efficient sets for Portfolios 3 to 5 and $\mathrm{MI}$ are shown in the table.

4. $r_{f}$ is the annual returns on the risk-free asset, taken from the People's Bank of China, was ranging from $1.98 \%$ to $10.98 \%$ during the study period.

\subsection{2 "Weak December" Effect}

As noted in Table 3, the lowest average monthly returns for five size-directed portfolios and MI all occur in December, which reveal the tendency of a "weak December" effect existing in the Chinese markets. The SD and SDR rules are again used to test whether this phenomenon exists in five size-directed portfolios and MI, the results are presented in Table 5. A number of conclusions can be drawn from this table.

Firstly, using the weak assumption of a non-decreasing utility function, one can effectively distinguish between the performance of December and non-December for five size-directed portfolios and MI. For example, January to August and October returns dominate December returns by the FSD rule (without lending and borrowing) for the smallest firm size portfolio (Portfolio 1). Similar results are also found for the other four size-directed portfolios and MI. When investors are allowed to borrow or lend money at a risk-free interest rate, June returns dominate December returns by FSDR rule for Portfolio 3. In order to distinguish the performance of between December and Non-December, we also need further assumption on the preference structure of investors.

Secondly, assuming risk aversion on investors' preferences, the results for five size-directed portfolios and MI show that December returns are dominated by all non-December returns; i.e., the December is excluded from their respective efficient sets when SSD rule is used to examine the dominance relationship between December and Non-December returns for each size-directed portfolio and MI.

In short, the results present in Table 5 clearly reveal that December returns are respectively dominated by non-December returns for all of the five size-directed portfolios and MI. In contrast to "strong March" effect, this finding is referred as to "weak December" effect in this study.

Table 5. Comparison of December and non-December Returns for Size-directed Portfolios and Market Index

\begin{tabular}{|c|c|c|c|c|c|c|}
\hline Month & $\begin{array}{c}\text { Portfolio } \\
1\end{array}$ & Portfolio 2 & $\begin{array}{c}\text { Portfolio } \\
3\end{array}$ & $\begin{array}{c}\text { Portfolio } \\
4\end{array}$ & $\begin{array}{c}\text { Portfolio } \\
5\end{array}$ & MI \\
\hline Jan & $\mathrm{FSD}^{1}$ & FSD & SSD & FSD & FSD & SSD \\
\hline Feb & FSD & FSD & FSD & SSD & SSD & FSD \\
\hline Mar & FSD & FSD & FSD & FSD & FSD & FSD \\
\hline Apr & FSD & FSD & FSD & FSD & FSD & FSD \\
\hline May & FSD & FSD & FSD & FSD & FSD & FSD \\
\hline Jun & FSD & FSD & FSDR & FSD & FSD & SSD \\
\hline Jul & FSD & FSD & FSD & FSD & FSD & FSD \\
\hline Aug & FSD & SSD & SSD & SSD & SSD & SSD \\
\hline Sep & SSD & SSD & SSD & SSD & SSD & SSD \\
\hline Oct & FSD & FSD & SSD & SSD & SSD & SSD \\
\hline Nov & SSD & SSD & SSD & SSD & SSD & SSD \\
\hline
\end{tabular}

1. FSD indicates that January returns dominate over December returns by FSD rule.

\section{3 "Strong March Size" Effect and "Weak December Size" Effect}

We have mentioned about that later studies point to the existence of January effect in the US stock markets, with most of these studies noting that the effect is particular strong for small firms. Rogalski and Tinic (1986) and Rathinasamy and Mantripragada (1996) named this phenomenon as January size effect in their papers. The above results respectively 
reveal the existence of "strong March" and "weak December" effects in the Chinese markets. Therefore, it is clearly of interest to investigate whether "strong March size" and "weak December size" effects also exist in the Chinese stocks, which are discussed below.

\subsection{1 "Strong March Size" Effect}

Figure 3 illustrates the CDFs of March Returns for five size-directed portfolios and MI during the study period. To construct the $\mathrm{CDF}$ for a given portfolio, the 13 realized monthly March returns are ranked in increasing order, with each observation having an equal probability of occurrence, so that each realized return is assigned a probability of 1/13. Hence, the lowest return has a cumulative probability of $1 / 13$, the second lowest return has a cumulative probability of 2/13, and so on. Finally, the highest return has a cumulative probability of 1.0. Plotting these points produces the CDF.

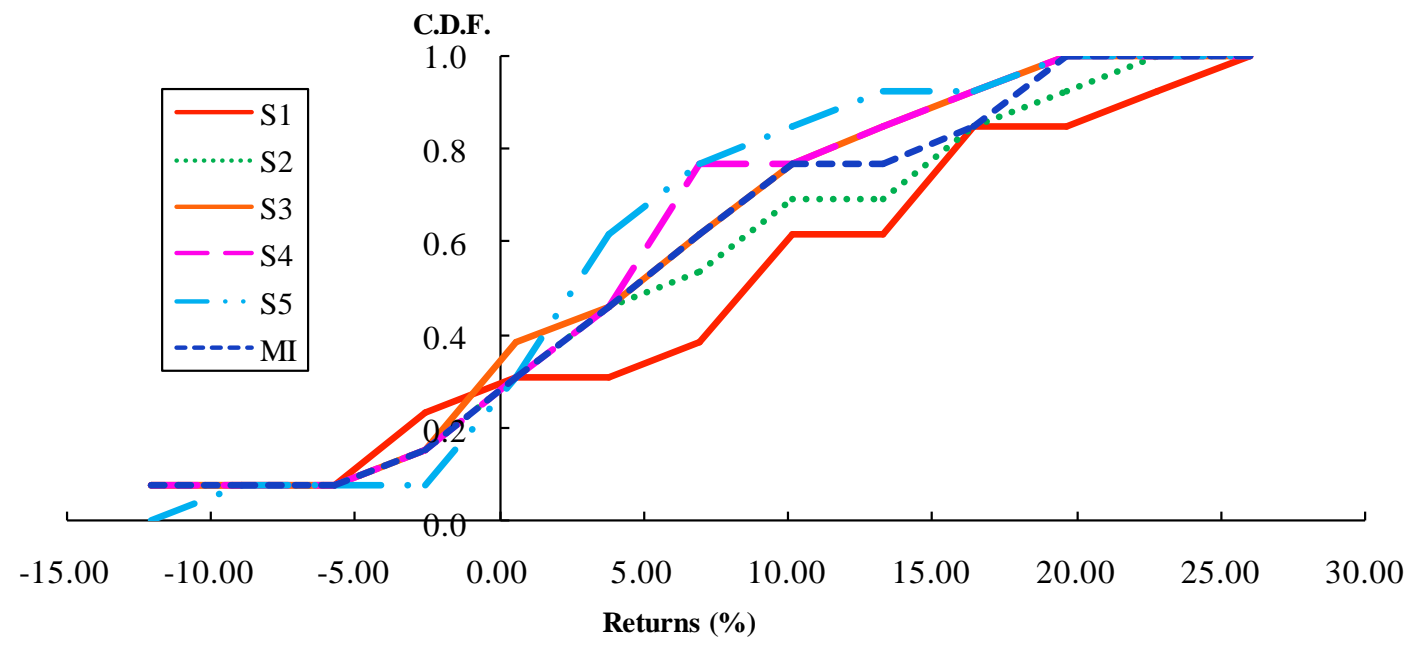

Figure 3. CDFs of March Returns for Five Size Portfolios and MI (S1 denotes the smallest-cap portfolio, S5 denotes the largest-cap portfolio, and MI denotes the Market Index.)

As shown in Figure 3, there is an almost monotonic ordering of the CDFs for the March returns by firm size. A visual of the figure shows that the CDF of the smallest firm size portfolio (Portfolio 1) is shifted most to the right, while the CDFs of the larger firm size portfolios and MI are shifted to the left, which implies that the March returns on the smallest firm size portfolio (Portfolio 1) may beat the March returns on the larger firm size-directed portfolios and MI by certain SD or SDR rules. Panel (a) of Table 6 shows the comparison of March returns for five size-directed portfolios and MI with and without transaction costs by SD or SDR rules. The following conclusions can be drawn from the first row of Table 6 (without transaction costs).

Firstly, under the weak assumption on investors' preferences, the performances of the various size-directed portfolios and MI can be weakly distinguished. We find that Portfolios 3 and 4 and MI of March are dominated by Portfolio 1 of March by FSD rule. As shown above, allowing investors to borrow or lend money at a certain risk-free interest rate can obtain a little strong result, the finding thus reveals that the Portfolio 2 of March is dominated by Portfolio 1 of March by FSDR rule; i.e., only Portfolio 5 of March are not outperformed by Portfolio 1 of March by FSDR rule. Thus, sharper decision rules are also required to distinguish the performance among the portfolios.

Secondly, under the assumption of the preferences of investors being risk averse, which is generally accepted by most economists, the stronger result is obtained; that is, the March returns on Portfolio 1 (the smallest firm size group) outperform the March returns on Portfolio 5 by SSDR rule, the implication of the results is that March returns on Portfolio 1 outperform the March returns on all of the other larger size-directed portfolios and MI. Furthermore, this result also implies that the March returns on Portfolio 1 dominate returns on all of the other 71 portfolios. 22

In order to examine whether this phenomenon continues to persist when transaction costs are taken into consideration, we assume that transaction costs are only charging for the March of the smallest firm portfolio (Portfolio 1). Transaction costs in the Chinese stock markets include tax stamp, commission fees and settlement fees. Investors pay commission and settlement fees of 3\%o of the trading value to the broker and a stamp tax when buying or selling stocks. Since the stamp tax rate varied several times during the research period, monthly returns are calculated in accordance with the

\footnotetext{
22 . The number of all of the other porfolios, including month-size portfolios and MI, is $(6 \times 12)-1=71$.
} 
stamp tax rate change. 23

The results of Panel (b) of Table 6, shown in the second row, show that even with the consideration of transaction costs, the March returns on the smallest firm size portfolio (Portfolios 1) continue to dominate the March returns on all of the larger size-directed portfolios and MI. This result suggests that holding on to stocks of the smallest firms in March remains to be a dominant strategy for investors even after considering transaction costs in the Chinese stock markets.

The above evidences show that the returns on the smallest firm size portfolio (Portfolio 1) in March are dominant over all of the other month-size portfolios and market index before and after transaction costs, which we refer to as "strong March size" effect in this study. Our interesting findings show that not only "strong March" effect but also "strong March size" effect exist in the Chinese stock markets, the evidences of which differ from the results in most developed stock markets. 24

\subsection{2 "Weak December Size" Effect}

The above results confirm the existence of the "strong March size" effect in the Chinese stock markets; therefore, it is clearly of further interesting to determine whether the "weak December size" effect also persists to exist before and after transaction costs. In order to carry out such analysis, we assume that transaction costs are charging for the size-directed Portfolios 2 to 5 and MI in December.

The results, presented in Panel (b) of Table 6, show that December returns of the smallest firm size portfolio (Portfolios 1) are dominated by the December returns of all of the other four larger size-directed portfolios and MI before and after transaction costs. Thus, our findings present that not only "weak December" effect but also "weak December size" effect exists in the Chinese stock markets, which are exceptional findings of the extant literature as well.

Table 6. A Comparison of March and December Returns among the Various Portfolios 1

(a) A Comparison between Portfolio 1 and the Other Four Size-directed Portfolios and MI for March Returns

\begin{tabular}{l|cccccc}
\hline & Portfolio 1 & Portfolio 2 & Portfolio 3 & Portfolio 4 & Portfolio 5 & MI \\
\hline Without Transaction Costs & - & FSDR $^{2}$ & FSD & FSD & SSDR & FSD \\
With Transaction Costs & - & SSDR & FSD & FSD & SSDR & FSD \\
\hline
\end{tabular}

1. The meaning of the symbol is the same as in the Table 4.

2. FSDR indicates that March returns on Portfolio 1 dominate March returns on Portfolio 2 by FSDR rule. Other symbols represent the similar meaning.

(b) A Comparison between Portfolio 1 and the Other Four Size-directed Portfolios and MI for December Returns

\begin{tabular}{c|cccccc}
\hline & Portfolio 1 & Portfolio 2 & Portfolio 3 & Portfolio 4 & Portfolio 5 & MI \\
\hline Without Transaction Costs & - & FSDR $^{3}$ & FSDR & FSDR & FSDR & FSDR \\
With Transaction Costs & - & SSD & FSDR & FSDR & FSDR & FSDR \\
\hline
\end{tabular}

3. FSDR indicates that December returns on Portfolio 2 dominate December returns on Portfolio 1 by FSDR rule.

\subsection{Discussion}

As noted above, tax-loss selling pressure and window dressing hypotheses may not provide any feasible explanation for the monthly effect in the Chinese markets; therefore, our new findings require other explanations. This study attempts to use consumption inertial hypothesis to explain the "strong March size" and "weak December size" effects in the Chinese stock markets.

Table 2 has mentioned that consumption expenditure tends to peak around December while a trough occurs in around March and April. In addition, high and positive stock returns generally correspond to low and negative growth rate of consumption (GRC), and vice versa. From the literature and the discussion in above section, we might reasonably conjecture that consumption expenditure may be used to explain "strong March size" and "weak December size" effects in the Chinese markets.

23 . The stamp tax rate ranges from $1 \%$ to $5 \%$ of the trading value during the study period.

${ }^{24}$. The market index of Shanghai and Shenzhen Stock Exchange respectively dramatically increased $100 \%$ and $70 \%$ for 2006 and 2007. It is doubtful whether the two effects still exist if these two years are deleted from the sample. The evidences show that the two effects still exist during the 1995-2005. 
Since the consumption expenditure series has an inherent unit root problem, 25 growth rate of consumption (GRC) is used to run the regression analysis. The independent variables include dummies for March (MAR) and December (DEC), with the growth rate of consumption (GRC) and monthly returns of the smallest firm size-directed portfolio $\left({ }^{r_{s 1}}\right)$ being the dependent variable in the regression analysis. The regression results are presented in Table 8.

As shown in Model (1), March dummy variable is positively significant at 5 per cent level and December dummy variable is negatively significant at 10 per cent level. These findings reconfirm our above stochastic dominance findings; that is, "strong March size" and "weak December size" effects concurrently exist in the smallest size-directed portfolio (Portfolio 1). Furthermore, the GRC, shown in Model (2), has a significantly negative impact on stock returns at 5 per cent level, which is consistent with the intuition of Figure 1. The implication of this result is that low (high) growth rate of consumption corresponds to high (low) stock returns and supports our consumption inertial hypothesis. That is, low and negative (high and positive) GRC around March (December) corresponds to high and positive (low and negative) returns.

Table 7. Explanation of the Monthly Effect with the Growth Rate of Consumption ${ }^{1}$

\begin{tabular}{cllllcc}
\hline & & & & \multicolumn{2}{c}{ Adjust } \\
Model & Intercept & GRC & MAR ${ }^{2}$ & DEC & R-square & F-statistic \\
\hline$(1)$ & $0.0256^{\text {a3 }}$ & & $0.0629^{\mathrm{b}}$ & $-0.0588^{\mathrm{c}}$ & & \\
& $(2.7055)^{4}$ & & $(2.0081)$ & $(-1.8773)$ & 0.0391 & 4.1555 \\
$(2)$ & 0.0288 & $-0.2273^{\mathrm{b}}$ & & & & \\
& $(3.2532)$ & $(-1.9094)$ & & & 0.0168 & 3.6456 \\
\hline
\end{tabular}

1. The dependent variable is monthly returns of the smallest firm size (Portfolio 1).

2. MAR and DEC respectively represent March and December dummies.

3. a, b and c represent significance at the $1 \%, 5 \%$ and $10 \%$ levels, respectively.

4. The figure in parentheses is t-value.

\section{Conclusions}

This study uses SD theory, a distribution-free, omitted risk-adjusted method and allowing investors to allocate their assets between risky and risk-free assets, to examine whether the monthly effect exists in the Chinese stock markets. Our main findings can be summarized as follows:

1) "Strong March" and "strong March size" effects are particularly found in the Chinese stock markets. That is, March returns for all five size-directed portfolios and market index respectively outperform their non-March returns and the returns for the smallest firm size portfolio in March are dominant over returns on all of the other month-size portfolios and market index.

2) "Weak December" and "weak December size" effects are also particularly found in the Chinese stock markets. That is, December returns for all five size-directed portfolios and market index are respectively dominated by their non-December returns and December returns for the smallest firm size portfolio are dominated by all of the other month-size portfolios and market index returns.

3) Compared with previous findings, our findings show that second-order stochastic dominance with a risk-free asset (SSDR) for March effect replaces first- or second-order stochastic dominance (FSD or SSD) for January effect.

4) Instead of tax-loss selling and window dressing hypotheses, the consumption inertial hypothesis can provide an explanation of the "strong March size" and "weak December size" effects in the Chinese markets.

Finally, our findings clearly differ from the results in the US and some developed markets and they also provide a strong indication that the monthly effects continue to present a serious challenge to the efficient markets hypothesis.

\section{References}

Aggarwal, R., Hiraki, T., \& Rao, R. P. (1990). Regularities in Tokyo Stock Exchange Security Returns: P/E, Size and Seasonal Influences. Journal of Financial Research, 13(3), 249-263.

Banz, R. W. (1981). The Relationship between Return and Market Value of Common Stocks. Journal of Financial

${ }^{25}$. Since the computed Augmented Dickey-Fuller (ADF) test-statistics (3.747) is greater than the critical values (-3.477, -2.882 and -2.578 at $1 \%, 5 \%$ and $10 \%$ significant level, respectively), which means that the consumption expenditure series has an unit root problem. 
Economics, 9(1), 3-18.

Barclay, M. J., Litzenberger, R. H., \& Warner, J. B. (1990). Private Information, Trading Volume and Stock-Return Variances. Review of Financial Studies, 3(2), 233-253.

Barone, E. (1990). The Italian Stock Market: Efficiency and Calendar Anomalies. Journal of Banking \& Finance, 14(2), 483-510.

Best, R. J., Best, R. W., \& Yoder, J. A. (2000). Value Stock and Market Efficiency. Journal of Economics and Finance, 24(1) 28-35.

Bhabra, S., Dhillon, U., \& Ramirez, G. (1999). A November Effect: Revisiting the Tax-Loss Selling Hypothesis. Financial Management, 28(4) 5-15.

Branch, B. S. (1977). A Tax Loss Trading Rule. Journal of Business, 50(2), 198-207.

Brown, P., Keim, D. B., Kleidon, A. W., \& Marsh, T. A. (1983). Stock Returns Seasonalities and the Tax Loss Selling Hypothesis: Analysis of the Arguments and Australian Evidence. Journal of Financial Economics, 12(1), 105-127.

Budría, S. (2008). An Exploration of Asset Returns in a Production Economy with Relative Habits. Atlantic Economic Journal, 36(3) 261-274.

CBSNEWS. (2009). As Goes January, So Goes the Year? http://www.cbsnews.com.

Chan, K. C., Chen, N. F., \& Hsieh, D. A. (1985). An Exploratory Investigation of the Firm Size Effect. Journal of Financial Economics, 14(3) 451-471.

Chen, H., \& Signal, V. (2004). All things Considered, Taxes Drive the January Effect. Journal of Financial Research, 27(3), 351-372.

Chou, S. R., \& Liao, T. L. (1996). The Relative Performance of the PER and PSR Filters with Stochastic Dominance: Evidence from the Taiwan Stock Exchange. Applied Financial Economics, 6(1), 19-27.

Dahlquist M., \& Sellin, P. (1996). Stochastic Dominance, Tax-Loss Selling and Seasonalities in Sweden. European Journal of Finance, 2(1), 1-19.

Dyl, E. A. (1977). Capital Gains Taxation and Year-End Stock Market Behavior. Journal of Finance, 32(1), $165-175$.

Elton, E. J., \& Gruber, M. J. (1995). Modern Portfolio Theory and Investment Analysis. Fifth Edition, John Wiley \& Sons, Inc.

Eun, C. S., \& Shim, S. (1989). International Transmission of Stock Market Movements. Journal of Financial and Quantitative Analysis, 24(2), 241-256.

Fama, E. F. (1970). The Efficient Capital Market: A Review of Theory and Empirical Work. Journal of Finance, 25(2), 383-417.

Gao, L., Kling, G.(2005). Calendar Effects in the Chinese Stock Market. Annals of Economics and Finance, 6(1), 75-88

Glosten, L. R., \& Milgrom, P. R. (1985). Bid, Ask and Transaction Prices in a Specialist Market with Heterogeneously Informed Traders. Journal of Financial Economics, 14(1), 71-100.

Gompers, P. A., Metrick, A. (2001). Institutional Investors and Equity Prices. Quarterly Journal of Economics, 116(1), 229-259.

Gu, Y. A. (2003). The Declining January Effect: Evidence from U.S. Equity Markets. Quarterly Review of Economics and Finance, 43(2) 395-404.

Gultekin, N., \& Gultekin, N. B. (1983). Stock Market Seasonality: International Evidence. Journal of Financial Economics, 12(4), 469-481.

Hadar, J., \& Russell, W. R. (1969). Rules for Ordering Uncertain Prospects. American Economic Review, 59(1), $25-34$.

Handa, P., Kothari, S. P., \& Wasley, C. (1989). The Relation between the Return Interval and Betas: Implications for the Size Effect. Journal of Financial Economics, 23(1), 79-100.

Hanoch, W. C., \& Levy, H. (1969). The Efficiency Analysis of Choice Involving Risk. Review of Economics Studies, $36(3), 335-346$.

Haug, M., \& Hirschey, M. (2006). The January Effect. Financial Analysts Journal, 62(5), 78-88.

Haugen, R. A., \& Lakonishok, J. (1988). The Incredible January Effect: The Stock Market's Unsolved Mystery, Dow Jones Irwin.

Haugen, R., \& Jorion, P. (1996). The January Effect: Still There after All These Years. Financial Analysts Journal, 52(1), 
27-31.

Hilliard, J. E. (1979). The Relationship between Equity Indices on World Exchanges. Journal of Finance, 34(1), 103-114.

Hirsch, J. A. (2009). The January Effect vs. the January Barometer. Wall Street Journal Website (http://www.marketwatch.com).

Ho, Y. K. (1990). Stock Return Seasonality in Asia Pacific Markets. Journal of International Financial Management and Accounting, 2(1), 47-77.

Jaffe, J., \& Westerfield, R. (1985). Patterns in Japanese Common Stock Returns: Day of Week and Turn of the Year Effects. Journal of Financial and Quantitative Analysis, 20(2), 261-272.

Jaffe, J., \& Westerfield, R. (1985). The Week-End Effect in Common Stock Returns: The International Evidence. Journal of Finance, 40(2), 433-454.

Keim, D. B. (1989). Trading Patterns, Bid-Ask Spread, and Estimated Security Returns: the Case of Common Stocks at Calendar Turning Points. Journal of Financial Economics, 25(1), 75-97.

Kim, D. (2006). On the Information Uncertainty Risk and the January Effect. Journal of Business, 79(4), $2127-2162$.

Kling, G., \& Gao, L. (2004). Do Chinese Institutional Investors Act Like Institutional Investors. Working Paper.

Kohers, T., \& Kohli, R. K. (1992). The Yearend Effect in Stock Returns over Business Cycles: A Technical Note. Journal of Economics and Finance, 16, 61-68.

Kramer, C. (1994). Macroeconomic Seasonality and the January Effect. Journal of Finance, 49(5), 1883-1891.

Kroll, Y., \& Levy, H. (1980). Stochastic Dominance: A Review and Some New Evidence. Research in Finance, 2, 163-227.

Lakonishok, J., Shleifer, A., Thaler, R., \& Vishny, R. (1991). Window Dressing by Pension Fund Managers. American Economic Review, 81(2), 227-231.

Lakonishok, J., \& Smidt, S. (1984). Volume and Turn of the Year Behavior. Journal of Financial Economics, 13(3), 435-456.

Lakonishok, J., \& Smidt, S. (1988). Are Seasonal Anomalies Real? A Ninety-Year Perspective. Review of Financial Studies, 1(4), 403-425.

Lean, H. H., Smyth, R., \& Wong, W. K. (2007). Revisiting Calendar Anomalies in Asian Stock Markets Using a Stochastic Dominance Approach. Journal of Multinational Financial Management, 17(3), 125-141.

Lettau, M., \& Ludvigson, S. (2001). Resurrecting the(C)CAPM: A Cross-Sectional Test When Risk Premia Are Time-Varying. Journal of Political Economy, 109(6), 1238-1287.

Levy, H., \& Sarnat, M. (1985). Investment and Portfolio Analysis, Wiley, New York, 178-231.

Levy, H. (1992). Stochastic Dominance and Expected Utility: Survey and Analysis. Management Science, 38(4), 555-593.

Levy, H. (1998). Stochastic Dominance: Investment Decision Making Under Uncertainty, Kluwer Academic Publishers, US.

Levy, H., \& Kroll, Y. (1976). Stochastic Dominance with Riskless Assets. Journal of Financial and Quantitative Analysis, 11(5), 743-773.

Levy, H., Kroll, Y., 1978. Ordering Uncertain Options with Borrowing and Lending. Journal of Finance, 33(2), 553-574.

Levy, H., Kroll, Y. (1979). Efficiency Analysis with Borrowing and Lending: Criteria and Their Effectiveness. Review of Economics and Statistics, 61(1), 125-130.

Levy, H., Lerman, Z., (1985. Testing P/E Ratios Filters with Stochastic Dominance. Journal of Portfolio Management $11(2), 31-40$.

Liao, T. L., Chou, S .R., (1995. Testing PSR Filters with Stochastic Approach. Journal of Portfolio Management, 21(3), 85-91.

Mehdian, S., Perry, M. J. (2002. Anomalies in US Equity Markets: A reexamination of the January Effect. Applied Financial Economics, 12(2), 141-145.

Moller, N., Zilca, S. (2008. The Evolution of the January Effect. Journal of Banking \& Finance, 32(3), $447-457$. 
Nassir, A., Mohammad, S., (1987. The January Effect of Stock Traded on the Kuala Lumpur Stock Exchange: An Empirical Analysis. Hong Kong, Journal of Business Management, 5, 35-50.

Officer, R. R., (1975. Seasonality in Australian Capital Markets: Market Efficiency and Empirical Issues. Journal of Financial Economics, 2(1), 29-52.

Ogden, J. P., (1990. Turn-of-Month Evaluations of Liquid Profits and Stock Returns: A Common Explanation for the Monthly and January Effects. Journal of Finance, 45(4), 1259-1272.

Pang, Q. K. L.(1988), An Analysis of the Hong Kong Stock Return Seasonality and Firm Size Anomalies for the Period 1977 to 1986. Hong Kong Journal of Business Management, 6, 69-90.

Post, T. (2003. Empirical Tests for Stochastic Dominance Efficiency. Journal of Finance, 58(5), 1905-1931.

Rathinasamy, R. S., Mantripragada, K. G., 1996. The January Size Effect Revisited: Is It a Case of Risk Mismeasurement? Journal of Financial and Strategic Decisions, 9(3), 9-14.

Reinganum, M. R. (1983). Misspecification of Capital Asset Pricing Model: Empirical Anomalies Bbased on Earnings Yields and Market Values. Journal of Finance Economics, 9(1), 19-46.

Ritter, J., Chopra, R. N. (1989). Portfolio Rebalancing and the Turn-of-the-Year Effect. Journal of Finance, 44(1), 149-166.

Rogalski, R. J., Tinic, S. M., (1986. The January Size Effect: Anomaly or Risk Mismeasurement? Financial Analysts Journal, 42(6), 63-70.

Rozeff, M. S., Kinney, W. R., (1976. Capital Market Seasonality: The Case of Stock Returns. Journal of Financial Economics, 3(4), 379-402.

Rozeff, M. S., (1986. Tax Loss Selling: Evidence from December Stock Return and Share Shifts. Proceedings of the Chicago CRSP Seminar on the Analysis of Security Prices, 9-45.

Seyhun, H. N., (1988. The January Effect and Aggregate Insider Trading. Journal of Finance, 43(1), $129-141$.

Seyhun, H. N., (1993. Can Omitted Risk Factors Explain January Effect: A Stochastic Dominance Approach. Journal of Financial and Quantitative Analysis, 28(2), 195-212.

Tinic, S. M., West, R. R., (1984. Risk and Return: January the Rest of the Year. Journal of Financial Economics, 13(4), 561-574.

Tinic, S. M., Rogalski, R. J., (1986. The January Size Effect: Anomaly or Risk Mismeasurement. Financial Analysts Journal, 42(6), 63-70.

Tinic, S. M., Giovanni, B. A., West, R. R., (1987. Seasonality in Canadian Stock Prices: A Test of the Tax-Loss Selling Hypothesis. Journal of Financial and Quantitative Analysis, 22(1), 51-63.

Wachtel, S. B., (1942. Certain Observations on Seasonal Movements in Stock Prices. Journal of Business, 15(2), 184-193.

Zang, X., Wang, L. (2006). An Analysis of the Consumption Risk and Aasset Returns of Chinese Residents. Frontiers of Economics in China, 1(3), 395-405.

\section{(cc) BY}

This work is licensed under a Creative Commons Attribution 3.0 License. 